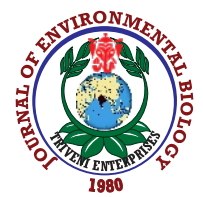

\title{
Soil carbon, microbial biomass carbon, soil health and productivity of toria (Brassica campestris L.) crop as affected by the application of organic manures
}

\author{
B. Gogoi ${ }^{1 *}$, B. Kalita ${ }^{2}$, I. Bhupenchandra ${ }^{3}$, P. Sutradhar ${ }^{4}$ and K.K. Sharma ${ }^{4}$ \\ 'Department of Soil Science, Assam Agricultural University, Jorhat-785 013, India \\ ${ }^{2}$ Regional Agricultural Research Station, Shillongani, Assam Agricultural University, Nagaon-782 002, India \\ ${ }^{3}$ ICAR-KVK Tamenglong, ICAR-RC for NEH Region, Imphal-795 004, India \\ ${ }^{4}$ Department of Agronomy, Assam Agricultural University, Jorhat-785 013, India \\ *Corresponding Author Email : bg100777@yahoo.co.uk
}

\section{Abstract}

Aim: To investigate the effect of different organic manures on the performance of toria crop and to understand their impact on the soil properties and availability of nutrients in acidic sandy loam soil.

Methodology: Three-year fixed plot study was conducted with 7 treatments viz., $T_{1}$ : control, $T_{2}$ : recommended dose of fertilizers (RDF), $T_{3}$ : cow dung manure @ 5 tha $^{-1}, \mathrm{~T}_{4}$ : pig dung manure @ 5 tha $^{-1}, \mathrm{~T}_{5}$ : goat dung manure @ $5 \mathrm{tha}^{-1}, \mathrm{~T}_{6}:$ farm yard manure $(\mathrm{FYM}) @ 5 \mathrm{tha}^{-1}$, and $\mathrm{T}_{7}$ : vermicompost @ $5 \mathrm{tha}^{-1}$ replicating 3 times in a complete randomized block design. Data were collected and analysed following the standard procedures. The yield and yield attributing parameters of toria and the soil properties such as soil pH, organic carbon, microbial biomass carbon and available NPK were studied.

Results: Application of different organic manures significantly affected the plant height, number of primary branches per plant, number of siliquae per branch, number of seeds siliqua and 1000-seed weight of toria crop. Addition of organic manure significantly enhanced the soil organic carbon, microbial biomass carbon and available NPK in the soil over initial, except soil $\mathrm{pH}$. The cost of cultivation, gross return and net return varied from $10.50 \times 10^{3}$ to $23.10 \times 10^{3}, 15.00 \times 10^{3}$ to 35.10 $\times 10^{3}$ and $4.46 \times 10^{3}$ to $19.96 \times 10^{3}$ Rs. ha $^{-1}$, respectively. The B:C ratio varied in the order of goat dung manure $>$ cow dung manure $>$ RDF $>$ FYM $>$ pig dung manure $>$ vermicompost $>$ control treatment.

Interpretation: To achieve maximum performance with nourishment of soil quality and health, application of vermicompost was confirmed to be the best over other organic sources of nutrients primarily due to enhancement in $\mathrm{C}$ and $\mathrm{N}$ status and an increase in microbial activities in soil.

Key words: Brassica compestris, Microbial biomass carbon, Organic manure, Soil properties

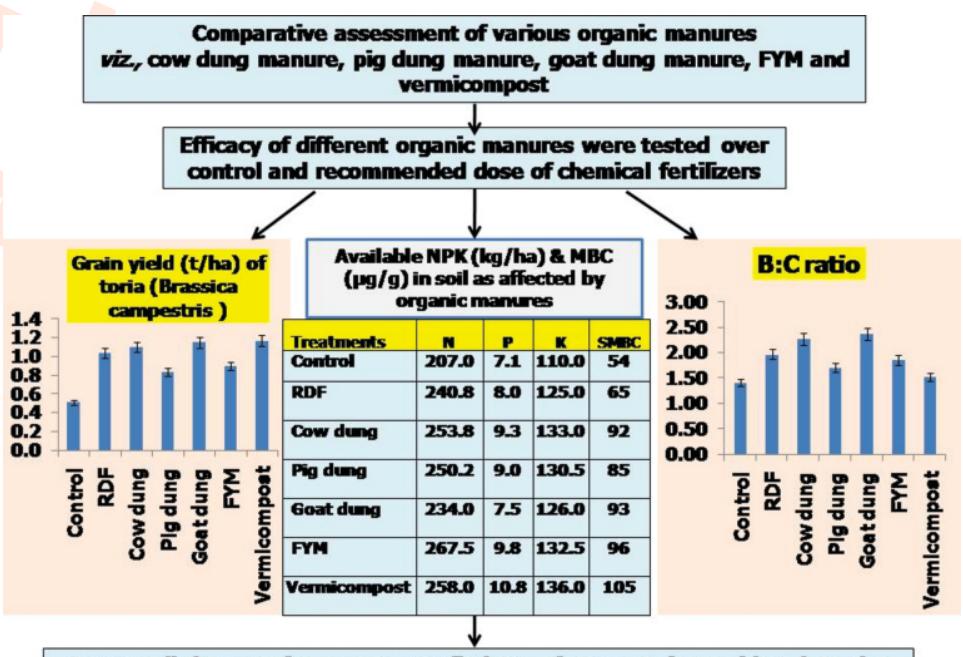

Among all the organic manures studied, vermicompost is considered to the best in terms of crop yield and soil health, whereas the highest B:C ratio was found in case of goat dung manure.

How to cite : Gogoi, B., B. Kalita, I. Bhupenchandra, P. Sutradhar and K.K. Sharma: Soil carbon, microbial biomass carbon, soil health and productivity of toria (Brassica campestris L.) crop as affected by the application of organic manures. J. Environ. Biol., 42, 1379-1386 (2021). 


\section{Introduction}

Livelihood security in a sustainable manner has immerged as the most important public issue in the recent agricultural system. Much attention has been paid to ensure food security without endangering the environmental and ecological stability. Agricultural sustainability depends to a large extent on improving the soil properties those controlled by many factors, of which the mineral nutrition is by and large most important (Baishya et al., 2015a). Declining trend in productivity due to continuous use of chemical fertilizers alone have been observed in several long term experiments (Nambiar, 1994), However, use of organic sources of nutrients sustains the soil productivity (Lal, 2004). Long-term experiments from India (Swarup and Wanjari, 2000; Nayak et al., 2012) and China (Liang et al., 2011) have confirmed that the addition of organic manures in fertility management program can progressively improve the soil health. The use and management of organic manures therefore are an increasingly important aspect of environmentally sound sustainable agriculture (Timsina and Connor, 2001).

Organic farming envisages a comprehensive management approach to improve soil health, ecosystem of the region and quality of produce. Of late, there is a growing interest among the farmers to cultivate crops under organic farming due to escalating cost of inorganic fertilizers, decreased soil fertility, environmental and health concerns due to pesticide usage and expected premium prices for organically grown crops (Ramesh et al., 2005). Organic amendments in organic farming play an essential role in nutrient management (Baishya et al., 2015b) and in improvement of soil health (Meelu et al., 1994). Organic manure has been used as a source of plant nutrients and organic matter to improve the fertility of agricultural lands for a long time (Dao and Cavigelli, 2003; Zhang et al., 2014). Several studies have shown the beneficial effects of organic manure on soil quality (Fares et al. 2008; Gezahegn and Martini, 2020). The soil properties (mainly microorganisms) are very responsive to organic inputs (Bolinder et al., 1999). Organic inputs enhance the development of microflora which ultimately improves the soil health (Nath et al., 2012). Therefore, additions of organic materials have direct impact in improving the soil fertility and productivity (Watson et al., 2002; Wong and Swift, 2003). Compost and animal manures enhance efficiency as the prime potential sources of nutrients in case of organic farming (Escobar and Hue, 2008). Decomposition of organic manure and release of nutrients are gradual and stored for a longer period in the soil, thus ensuring longer residual effect and improved crop yields (Gezahegn and Martini, 2020). Organic manures not only supply nutrients in available forms to the plants but simultaneously improve the physico-chemical and biological properties of the soil (Das et al., 2017; Choudhary and Rahi, 2018). Addition of compost and animal manures primarily increase the soil organic matter content which ultimately augments the soil's biological population and biodiversity (Roy and Kashem, 2014). Soil organic matter undergoes mineralization and releases substantial quantities of macronutrients and smaller amount of micronutrients (Rahman et al., 2013).

Toria (Brassica campestries L.) is a major oil seed crop grown during rabi season in north-east India. Organic cultivation of toria crop is essential for producing quality toria oil devoid of toxic residuals. This crop is highly responsive to organic manuring (Yadav et al., 2013). With the advantages of minimum use of fertilizer, availability of plant- and livestock-excreta-based organic manure (about 46 million tonnes) and pesticides, and favourable climatic conditions (Bujarbaruah, 2004; Patel et al., 2014) there have a great scope for the farming community of north-east India to grow toria crop under organic production system. Considering the demand of organic products, the toria farmers could have received higher income through cultivation of toria under organic management system. In general farmers of North-east region of India prefer locally available compost and animal manures (like farm yard manure, vermicompost, cow dung, goat and pig manure for crop production. Therefore, the effect of locally available organic sources of nutrients on soil health and quality to meet the crop nutrient requirements under organic production system must be understood properly. Therefore, this study was carried out to determine the effect of compost and animal manures on productivity, profitability and quality traits of toria crop. Further, the changes in soil properties amended with farm yard manure, vermicompost, pig dung manure, goat and cow dung manure was examined.

\section{Materials and Methods}

The experiments were carried out during rabiseason from 2016-17 to 2018-19 (for 3 crop cycles) in case of toria crop at Regional Agricultural Research Station, Assam Agricultural University, Gossaigaon, Assam. The soil of the experimental site was acidic ( $\mathrm{pH} 4.9$ ), sandy loam in texture, oxidizable SOC- $4.30 \mathrm{~g}$ $\mathrm{kg}^{1}$, microbial biomass carbon- $57.0 \mathrm{mg} \mathrm{kg}$, available $\mathrm{N}-238.7 \mathrm{~kg}$ ha ${ }^{-1}$, available P- $8.87 \mathrm{~kg} \mathrm{ha}^{-1}$ and available K-127.7 $\mathrm{kg} \mathrm{ha}^{-1}$. Therefore, the soil was low in organic carbon, available $\mathrm{N}$ and $\mathrm{P}$ and medium in available $\mathrm{K}$. The experiment was established in randomized block design with 7 treatments viz., $\mathrm{T}_{1}$ : control, $\mathrm{T}_{2}$ : recommended dose of fertilizers (RDF), $T_{3}$ : cow dung manure @ 5 tha ${ }^{-1}, T_{4}$ : pig dung manure @ $5 \mathrm{tha}^{-1}, \mathrm{~T}_{5}:$ goat dung manure @ $5 \mathrm{t}$ $h^{-1}{ }^{-1} T_{6}$ : farm yard manure (FYM) @ 5 tha $^{-1}$ and $T_{7}$ : vermicompost @ 5 tha ${ }^{-1}$. Nutrient content (N, $\mathrm{P}$ and $\mathrm{K}$ ) of the manures used in this study was analysed and is given in the Table 1. The selected treatments were tested replicating thrice. The recommended level of nitrogen, phosphorus and potassium $\left(40,35\right.$ and $\left.15 \mathrm{~kg} \mathrm{ha}^{-1}\right)$ for toria crop were applied as basal (in $\mathrm{T}_{2}$ ) in the form of urea, single super phosphate and muriate of potash, respectively. All the manures used as organic source of nutrients were applied as basal, 10 days prior to seed sowing. 
Table 1: Nutrient content (\%) of different organic sources (on dry-weight basis)

\begin{tabular}{llll}
\hline Organic sources & Nitrogen & Phosphorus & Potassium \\
\hline Cow dung manure & $0.50-0.52$ & $0.20-0.25$ & $0.40-0.45$ \\
Pig dung manure & $0.30-0.40$ & $0.15-0.25$ & $0.25-0.40$ \\
Goat dung manure & $0.55-0.65$ & $0.40-0.47$ & $0.37-0.40$ \\
Farm yard manure & $0.45-0.50$ & $0.20-0.24$ & $0.35-0.40$ \\
Vermicompost & $0.80-1.05$ & $0.52-0.60$ & $0.70-0.85$ \\
\hline
\end{tabular}

Toria (cv. TS 36) was sown in October and harvested in February. All crop management practices were followed as per the standard recommendations of the region. The plant height (cm) and number of primary branches per plant was counted at crop maturity in ten tagged plants in net plot. The yield attributing parameters were computed using standard procedures (Rana et al., 2014). The seed yield was recorded at $12 \%$ moisture content.

After harvest of toria crop, processed soil samples (0-30 $\mathrm{cm}$ depth) were analyzed for $\mathrm{pH}$ in 1:2.5 soil-water suspensions by Glass Electrode pH Meter (Jackson, 1973). Organic carbon content of soil and organic manures was estimated by wet digestion method (Walkley and Black, 1934). Available nitrogen, phosphorus and potassium content in soil and organic manures were determined by alkaline potassium permanganate method (Subbiah and Asija, 1956), Bray and Kurtz No.1 method and flame photometrically (Jackson, 1973). Field moist samples were collected and preserved in refrigerator at $4^{\circ} \mathrm{C}$ temperature for estimating microbial biomass carbon (MBC) in soil. Soil MBC was estimated by chloroform fumigation extraction method (Jenkinson and Powlson, 1976) calculated by the equation, $M B C=E_{c} / k_{E C}$, where $E_{c}$ is the difference between $C$ extracted from the fumigated and non-fumigated soil extracts and $k_{E C}=0.38$ and expressed as $\mu \mathrm{gg}^{-1}$ soil.

Considering the prevailing price during the study time, the cost of cultivation included cost of land preparation and labour cost including the cost of inputs such as seed, fertilizers, manures etc. Economics was worked out by taking mean toria seed yields of 3 years. All the data obtained from the experiments conducted for 3 consecutive years were averaged and subjected to statistical analysis as per the procedure outlined by Gomez and Gomez(1984).

\section{Results and Discussion}

The effect of different organic manures on yield attributing parameters of toria was significant (Table 2). Plant height of toria varied from $38.8 \mathrm{~cm}$ under control $\left(T_{1}\right)$ to $99.1 \mathrm{~cm}$ under pig dung manure $5 \mathrm{tha}^{-1}\left(\mathrm{~T}_{4}\right)$. Application of recommended dose of fertilizers $\left(T_{2}\right)$ and goat dung manure @ 5 t ha $^{-1}\left(T_{5}\right)$ recorded the highest number of primary branches per plant (4.7) followed by vermicompost @ 5 t ha $^{-1}\left(\mathrm{~T}_{7}\right)$ treatment. The number of siliquae per branch of toria crop varied from 27.3 to 13.5 whereas the number of seeds per siliqua ranged between 9.4 and 16.0. The highest number of siliquae per branch (27.3) was recorded in $T_{7}$ (vermicompost 5 tha $^{-1}$ ) treatment followed by $\mathrm{T}_{6}\left(\mathrm{FYM} \mathrm{t} \mathrm{tha}^{-1}\right)$ and $\mathrm{T}_{2}$ (RDF) treatments. The number of seeds per siliqua (16.0) was highest in $T_{7}$ followed by $T_{5}$. The 1000 seed weight varied significantly between 2.30 to $3.68 \mathrm{~g}$ in different organic manures. The highest 1000 seed weight was recorded in pig dung manure followed by vermicompost and goat dung manure.

Addition of organic manures improved the growth of toria crop due to improvement in soil fertility and productivity (Table 3). The improvement in yield attributing parameters of crops could be attributed to slow decomposing nature of manures which helped in availability of macro and micro nutrients throughout the crop growth period. Lepcha et al. (2019) reported that increased soil available nutrient favourably influenced the root growth and development, thereby indirectly increased the yield attributing parameters. Organic materials contain growth regulating substances such as auxins, gibberellins, cytokinins and humic substances (Atiyeh et al., 2002; Guzman-Albores et al., 2020) which are responsible for the growth and development of crops. Application of organic manures enhances the microbial activity and nutrient availability in soil which ultimately increases the crop growth (Vipitha and Geethakumari, 2015).

The effect of organic manures on the yield of toria crop was statistically significant (Table 2). The seed and stover yield of toria varied from 0.51 to 1.17 and 1.57 to $4.02 \mathrm{t} \mathrm{ha}^{-1}$, respectively. The highest seed and stover yields of toria were recorded in $T_{7}$ (vermicompost $5 \mathrm{t} \mathrm{ha}^{-1}$ ) treatment, followed by $\mathrm{T}_{5}$ (goat dung manure $5 \mathrm{tha}^{-1}$ ) and $\mathrm{T}_{3}$ (cow dung manure $5 \mathrm{tha}^{-1}$ ) treatments. The significantly lowest toria yield was recorded in control $\left(T_{1}\right)$ receiving no any external sources of nutrients. Similar trend was observed in the biological yield of toria crop which ranged between $2.08\left(T_{1}\right)$ and $5.19 \mathrm{t} \mathrm{ha}^{-1}\left(\mathrm{~T}_{7}\right)$. The stover and seed yield ratio of toria varied from $3.1\left(T_{1}\right)$ to $4.2\left(T_{4}\right)$ (Table 2). A 129.4\% higher grain yield of toria was recorded on applying vermicompost @ 5 t ha $^{-1}$ over control. Ghanshyam et al. (2010) reported that application of FYM and vermicompost could increase the crop yield by $30.5 \%$ over no-manures and this increase could be due to adequate release and supply of nutrients from the organic manures. The physico-chemical and biological properties of soil were improved on adding manures to the soil (Ould Ahmed et al. 2010), which ultimately increased the crop yield. Crop yield increment as a result of organic amendments in soil was also 
Table 2: Yield and yield attributing characteristics of toria (cv. TS 36) as affected by different sources of organic manures (mean value of 3 years)

\begin{tabular}{|c|c|c|c|c|c|c|c|c|c|c|}
\hline Treatments & $\begin{array}{l}\text { Plant } \\
\text { height } \\
(\mathrm{cm})\end{array}$ & $\begin{array}{l}\text { Number } \\
\text { of primary } \\
\text { branches } \\
\text { per plant }\end{array}$ & $\begin{array}{l}\text { Number of } \\
\text { siliquae } \\
\text { per branch }\end{array}$ & $\begin{array}{l}\text { Number of } \\
\text { seeds per } \\
\text { siliqua }\end{array}$ & $\begin{array}{l}1000 \text { seed } \\
\text { weight } \\
\text { (g) }\end{array}$ & $\begin{array}{l}\text { Grain } \\
\text { yield } \\
\left(\text { tha }^{-1}\right)\end{array}$ & $\begin{array}{l}\text { Stover } \\
\text { yield } \\
\left(\mathrm{tha}^{-1}\right)\end{array}$ & $\begin{array}{l}\text { Biological } \\
\text { yield } \\
\left(\mathrm{t} \mathrm{ha}^{-1}\right)\end{array}$ & $\begin{array}{l}\text { Stover } \\
\text { and Seed } \\
\text { yield ratio }\end{array}$ & $\begin{array}{l}\text { Harvest } \\
\text { index } \\
(\%)\end{array}$ \\
\hline $\mathrm{T}_{1}$ & 38.8 & 3.0 & 13.5 & 9.4 & 2.30 & 0.51 & 1.57 & 2.08 & 3.1 & 24.5 \\
\hline $\mathrm{T}_{2}$ & 94.6 & 4.7 & 25.0 & 12.4 & 2.83 & 1.04 & 3.90 & 4.94 & 3.8 & 21.1 \\
\hline $\mathrm{T}_{3}$ & 86.9 & 4.2 & 24.1 & 15.0 & 2.71 & 1.10 & 3.92 & 5.02 & 3.6 & 21.9 \\
\hline $\mathrm{T}_{4}$ & 99.1 & 4.4 & 18.7 & 13.0 & 3.68 & 0.83 & 3.45 & 4.28 & 4.2 & 19.4 \\
\hline $\mathrm{T}_{5}$ & 78.4 & 4.7 & 24.5 & 16.0 & 2.85 & 1.15 & 3.97 & 5.12 & 3.4 & 22.5 \\
\hline $\mathrm{T}_{6}$ & 68.6 & 4.0 & 25.7 & 14.4 & 2.47 & 0.90 & 3.60 & 4.50 & 4.0 & 20.0 \\
\hline $\mathrm{T}_{7}$ & 92.5 & 4.6 & 27.3 & 16.0 & 2.86 & 1.17 & 4.02 & 5.19 & 3.4 & 22.5 \\
\hline $\operatorname{SEm}( \pm)$ & 1.19 & 0.14 & 2.18 & 0.67 & 0.07 & 0.05 & 0.13 & 0.35 & 0.04 & 0.35 \\
\hline$C D(P=0.05)$ & 3.69 & 0.43 & 6.80 & 1.92 & 0.21 & 0.15 & 0.34 & 1.10 & 0.12 & 1.1 \\
\hline
\end{tabular}

$\mathrm{T}_{1}$ : Control; $\mathrm{T}_{2}:$ Recommended dose of fertilizers; $\mathrm{T}_{3}:$ Cow dung manure @ 5 tha ${ }^{-1} ; \mathrm{T}_{4}:$ Pig dung manure @ 5 tha ${ }^{-1} ; \mathrm{T}_{5}:$ Goat dung manure @ 5 tha ${ }^{-1} ; \mathrm{T}_{6}:$ FYM @ 5 tha ${ }^{-1} ; \mathrm{T}_{7}:$ Vermicompost @ 5tha-1. RDF: Recommended dose of fertilizers $\left(40-35-15 \mathrm{~N}-\mathrm{P}_{2} \mathrm{O}_{5}-\mathrm{K}_{2} \mathrm{O} \mathrm{kg} \mathrm{ha-1}\right)$.

reported by Sanker et al. (2009) and Lepcha et al. (2019).

The harvest index of toria crop varied between 19.4 to $24.5 \%$ (Table 2). It was significantly highest in control receiving no any external source of nutrients which might be attributed to the fact that stover and seed yield ratio (3.1) was lowest in this treatment. The second highest harvest index (22.5) was recorded in goat dung manure and vermicompost with the same stover and seed yield ratio (3.4) of toria crop. The lowest harvest index was recorded in pig dung manure was due to the highest stover and seed yield ratio of toria crop (4.2).

The soil health was assessed in terms of change in soil $\mathrm{pH}$, soil organic carbon, microbial biomass carbon and available NPK in the post harvest soils of toria. The changes in soil pH upon addition of organic materials under toria crop was non-significant (Table 3) and data varied from 4.80 to 5.12. Over initial (4.91), there was a slight reduction in soil pH under control and RDF treatments. However, soil pH increased over initial due to addition of organic manures. The highest $\mathrm{pH}$ (5.12) was recorded in vermicompost followed by goat dung manure and FYM. The higher $\mathrm{pH}$ in the plots with organic manure treatments may be defined as deactivation of $\mathrm{Al}^{3+}$ and concomitant release of basic cations due to supplementation of nutrients with organic sources (Gogoi, 2011; Baishya et al., 2015a). During oxidation of organic matter, ferric iron is used as an electron-acceptor and during this process $\mathrm{H}^{+}$ions are neutralized leading to decrease in soil acidity. Such rise in soil pH due to application of organic manures is in conformity with the findings of earlier workers (Azeez and Van Averbeke, 2012; Avasthe et al., 2020).

Different organic manures exerted favourable effect on the soil organic carbon in toria crop. The soil organic carbon varied between 4.5 to $5.5 \mathrm{~g} \mathrm{~kg}^{-1}$ (Table 3) and increased significantly in all the treatments under study over the initial SOC $\left(4.3 \mathrm{~g} \mathrm{~kg}^{-1}\right)$. The treatments receiving organic manures recorded
13.3-22.2 and 6.3-14.6\% increase in SOC over control and RDF, respectively. The highest increase in $\mathrm{SOC}$ was recorded in goat dung manure and vermicompost treatment followed by FYM. The increase in SOC in control and RDF treatment over initial may be attributed to the left-over stover and root biomass of toria crop which contributed to increased organic carbon content in soil. Further, addition of cow dung manure, pig dung manure, goat dung manure, FYM and vermicompost might have increased the SOC in $T_{3}, T_{4}, T_{5}, T_{6}$ and $T_{7}$, respectively. Previous studies reported that repeated application of manure can increase SOC level (Dao and Cavigellib, 2003; Maillard and Angers 2014; Gezahegn and Martini, 2020). Significant positive correlation between SOC content and the addition of carbon input in soil was reported by Babu et al., (2020). It was obvious from the present study that an increase in SOC under organic cultivation of crops could be accredited to numerous factors but type of organic manures is the most significant driver. The addition of organic manures might have increased the food sources ( $\mathrm{C}$ and $\mathrm{N}$ content) for the microorganisms, and thus enhanced the microbial activities helping in the decomposition of organic matter. Increase in SOC as a result of priming effect of microbial activity following organic manure application in the soils of Bhopal was reported by Aher et al. (2019).

Application of organic manures in toria crop showed an increase in microbial biomass carbon (MBC) in soil over initial (57 $\left.\mu \mathrm{g} \mathrm{g}^{-1}\right)$. The soil MBC differed significantly and data varied from 54.2 to $105.2 \mu \mathrm{g} \mathrm{g}^{-1}$, which represented 1.2 to $1.9 \%$ of total organic carbon in soil (Table 3). The lower value of MBC recorded in control treatment did not fit within those reported by Vance et al. (1987) for various terrestrial ecosystems (61- $1900 \mu \mathrm{g} \mathrm{g}{ }^{-1}$ ) which might be due to the fact that the control plot was not receiving any external sources of nutrients in the soil, which was sandy loam in texture. In contrast, the highest MBC in soil $\left(105.2 \mu \mathrm{g} \mathrm{g}{ }^{-1}\right)$ was recorded in the plot receiving vermicompost @ 5 tha $^{-1}$, followed by 
Table 3 : Post harvest soil properties as affected by different sources of organic manures in toria crop (cv. TS 36) (mean value of 3 years)

\begin{tabular}{|c|c|c|c|c|c|c|c|}
\hline Treatments & $\begin{array}{l}\text { Soil pH ( } 1: 2.5 \text { soil-water } \\
\text { suspensions) }\end{array}$ & $\begin{array}{l}\text { SOC } \\
\left(g_{k g}^{-1}\right)\end{array}$ & $\begin{array}{l}\text { SMBC } \\
\left(\mu g g^{-1}\right)\end{array}$ & $\begin{array}{l}\text { SMBC } \% \\
\text { of SOC }\end{array}$ & $\begin{array}{l}\text { Avail. N } \\
\left(\mathrm{kg} \mathrm{ha}^{-1}\right)\end{array}$ & $\begin{array}{l}\text { Avail. } P \\
\left(\mathrm{~kg} \mathrm{ha}^{-1}\right)\end{array}$ & $\begin{array}{l}\text { Avail. K } \\
\left(\mathrm{kg} \mathrm{ha}^{-1}\right)\end{array}$ \\
\hline $\mathrm{T}_{1}$ & 4.80 & 4.5 & 54.2 & 1.20 & 207.0 & 7.10 & 110.0 \\
\hline $\mathrm{T}_{2}$ & 4.88 & 4.8 & 65.4 & 1.36 & 240.8 & 8.00 & 125.0 \\
\hline $\mathrm{T}_{3}$ & 5.00 & 5.1 & 92.2 & 1.81 & 253.8 & 9.26 & 133.0 \\
\hline $\mathrm{T}_{4}$ & 5.03 & 5.2 & 84.5 & 1.63 & 234.0 & 7.50 & 126.0 \\
\hline $\mathrm{T}_{5}$ & 5.11 & 5.5 & 92.7 & 1.69 & 267.5 & 9.84 & 132.5 \\
\hline $\mathrm{T}_{6}$ & 5.10 & 5.4 & 95.5 & 1.77 & 250.2 & 9.00 & 130.5 \\
\hline $\mathrm{T}_{7}$ & 5.12 & 5.5 & 105.2 & 1.91 & 258.0 & 10.80 & 136.0 \\
\hline Initial & 4.91 & 4.3 & 57.0 & 1.33 & 238.7 & 8.87 & 127.7 \\
\hline SEm $( \pm)$ & 0.09 & 0.09 & 1.6 & 0.01 & 2.62 & 0.26 & 2.37 \\
\hline$C D(P=0.05)$ & NS & 0.30 & 5.0 & 0.04 & 8.18 & 0.80 & 7.37 \\
\hline
\end{tabular}

$\mathrm{T}_{1}$ : Control; $\mathrm{T}_{2}:$ Recommended dose of fertilizers; $\mathrm{T}_{3}:$ Cow dung manure @ 5 tha ${ }^{-1} ; \mathrm{T}_{4}:$ Pig dung manure @ 5 tha ${ }^{-1} ; \mathrm{T}_{5}:$ Goat dung manure @ 5 tha ${ }^{-1} ; \mathrm{T}_{6}: \mathrm{FYM}$

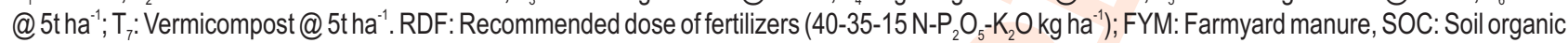
carbon and SMBC: soil microbial biomass carbon

FYM $\left(95.5 \mu \mathrm{g} \mathrm{g}^{-1}\right)$ and goat dung manure $\left(92.7 \mu \mathrm{g} \mathrm{g}^{-1}\right)$. Changes in the quality of organic manures might have influenced microbial population and activity through changes in substrate supply, aeration status, and associated soil physical properties (Choudhary et al., 2018) which were demonstrated by the changes in soil MBC in this study. The result revealed that there was $48.2-84.6 \%$ increase in MBC over initial due to addition of various organic materials in toria crop in sandy loam soils. The supply and availability of supplementary mineralizable and readily hydrolysable carbon due to organic manure application might be the probable cause of higher microbial activity and MBC in soil. An increased MBC with organic amendments in soil was also reported by Nagar et al. (2016) and Ram et al. (2019). Gogoi et al. (2010) reported that addition of organic manures provide favourable $\mathrm{C}: \mathrm{N}$ ratio for higher activity of soil microbes which was indicated by enhanced MBC in soil. Manna et al. (1996) and Kaur and Brar (2008) found higher MBC in soil with the application of organic manures due to higher availability of substrate as carbon from applied organic manure, intense rooting activity and better soil water status in soil.

Addition of various organic materials such as cow dung manure, pig dung manure, goat dung manure, FYM and vermicompost significantly increased the available primary nutrients over control in sandy loam soils of Assam (Table 3). The available $\mathrm{N}, \mathrm{P}$ and $\mathrm{K}$ in soil varied from 207.0 to $267.5,7.1$ to 10.8 and 110.0 to $136.0 \mathrm{~kg} \mathrm{ha}^{-1}$, respectively.

The available N, $P$ and $K$ increased by 13.0-24.6, 5.6-52.1 and $14.5-23.6 \%$, respectively, due to addition of organic manures in soil under toria crop. Addition of vermicompost @ 5 t ha ${ }^{-1}$ was found to be the best among others so far as the availability of NPK was concerned whereas application of pig dung manure was recorded as low-graded in case of toria crop. Guzman-Albores et al. (2020) showed $42 \%$ increase in nitrogen, $29 \%$ phosphorus and $57 \%$ potassium with the addition of vermicompost in soil. In this study, the lowest availability with a negative balance of primary nutrients were found in the control plot receiving no external source of nutrients, while a mild decrease in available $\mathrm{N}$, $\mathrm{P}$ and $\mathrm{K}$ was observed in RDF over the initial. Higher available nutrients in the organic manure treated plots could be attributed to release of inorganic forms of nutrients from added organics. Organic manures release organic molecules which can inhibit nutrient adsorption in soil (Haynes and Mokolobate, 2001). Rahman et al. (2013) reported that mineralization of nutrients is influenced by the amount and type of organic materials, moisture regime and type of soil. Patra et al. (2011) reported that application of organic manure significantly increase soil available nitrogen due to higher multiplication of microbes. Increase in phosphorus availability under organic manure treated plots might have resulted from reduction in phosphorus fixation and increased mineralization of phosphorus. Decomposition of organic sources of nutrients produce various organic acids which solubilize phosphorus and other phosphate bearing minerals and thereby increase phosphorus availability in soil. Patra et al. (2011) reported that complex organic anions chelate $\mathrm{Al}^{+3}, \mathrm{Fe}^{+3}$ and $\mathrm{Ca}^{+3}$, and thus decrease the phosphorus precipitating power of these cations thereby increasing the phosphorus availability. Such encouraging effect of organic manures in enhancing the availability of phosphorus was also noted by Baishya et al. (2015a) and Patel et al. (2018). Increased availability of potassium supplemented with organic sources might be due to the combined effect of direct addition of potassium to the available pool of soil, mineralization of organic sources and solubilization from native sources during decomposition (Gogoi, 2011). Application of organic manure secreted organic acid during the process of decomposition which led to mineralization of fixed potassium and increased the availability of potassium. Moreover humus retains divalent cations $\left(\mathrm{Ca}^{+2}, \mathrm{Mg}^{+2}\right)$ more strongly than monovalent cations. Hence, weaker retention of potassium relative to calcium and magnesium may increase potassium availability (Nagar et al., 2016; Jadhao et al., 2018). Thus, 
Table 4 : Economics of toria crop cultivation with different sources of organic manures (mean value of 3 years)

\begin{tabular}{|c|c|c|c|c|}
\hline Treatments & $\begin{array}{l}\text { Cost of cultivation } \\
\left(\times 10^{3} \mathrm{Rs}^{-h^{-1}}\right)\end{array}$ & $\begin{array}{l}\text { Gross return } \\
\left(\times 10^{3} \mathrm{Rs}^{-h^{-1}}\right)\end{array}$ & $\begin{array}{l}\text { Net return } \\
\left(\times 10^{3} \mathrm{Rs}_{\mathrm{h}} \mathrm{ha}^{-1}\right)\end{array}$ & Benefit: Cost ratio \\
\hline $\mathrm{T}_{1}$ & 10.54 & 15.00 & 4.46 & 1.42 \\
\hline $\mathrm{T}_{2}$ & 15.87 & 31.20 & 15.33 & 1.97 \\
\hline $\mathrm{T}_{3}$ & 14.54 & 33.00 & 18.46 & 2.27 \\
\hline $\mathrm{T}_{4}$ & 14.54 & 24.90 & 10.36 & 1.71 \\
\hline $\mathrm{T}_{5}$ & 14.54 & 34.50 & 19.96 & 2.37 \\
\hline $\mathrm{T}_{6}$ & 14.54 & 27.00 & 12.46 & 1.86 \\
\hline $\mathrm{T}_{7}$ & 23.10 & 35.10 & 12.00 & 1.52 \\
\hline $\operatorname{SEm}( \pm)$ & - & - & - & 0.04 \\
\hline$C D(P=0.05)$ & - & - & - & 0.12 \\
\hline
\end{tabular}

$\mathrm{T}_{1}$ : Control; $\mathrm{T}_{2}:$ Recommended dose of fertilizers; $\mathrm{T}_{3}:$ Cow dung manure @ 5 tha ${ }^{-1} ; \mathrm{T}_{4}:$ Pig dung manure @ 5 tha ${ }^{-1} ; \mathrm{T}_{5}:$ Goat dung manure @ 5 tha ${ }^{-1} ; \mathrm{T}_{6}: \mathrm{FYM}$ @ 5 tha ${ }^{-1} ; \mathrm{T}_{7}:$ Vermicompost @ 5tha ${ }^{-1}$.RDF: Recommended dose of fertilizers (40-35-15 N- $\left.\mathrm{P}_{2} \mathrm{O}_{5}-\mathrm{K}_{2} \mathrm{O} \mathrm{kg} \mathrm{ha-1}\right)$; FYM: Farmyard manure

significant increase in available nutrients in soil was due to increased mineralization of organic nutrients by active microorganisms and the regular dynamics of biomass carbon (Nardi et al., 2004; Vel Murugan and Swarnam, 2013; Roy and Kashem, 2014).

The economics of toria crop cultivation with different sources of organic manures are presented in Table 4. The cost of cultivation of toria crop varied from the lowest $10.50 \times 10^{3} \mathrm{Rs}^{-\mathrm{ha}^{-1}}$ under $T_{1}$ to $23.10 \times 10^{3} \mathrm{Rs}$. ha ${ }^{-1}$ under $T_{7}$. The same amount of cost of cultivation (14.54 X10 ${ }^{3}$ Rs. ha ${ }^{-1}$ ) for $T_{3}, T_{4}, T_{5}$ and $T_{6}$ treatments may be due to the price of organic sources of nutrients viz., cow dung manure, pig dung manure, goat dung manure and FYM were considered as same in the present study. The highest gross return was recorded with application of vermicompost @ $5 \mathrm{t} \mathrm{ha}^{-1}$ followed by goat dung @5 tha ${ }^{-1}$. However, the net return was found to highest in $T_{5}$, followed by $T_{3}$ receiving cow dung manure. Cultivation of toria crop with the application of goat dung manure was recorded with the highest $B: C$ ratio (2.37) followed by application of cow dung manure (2.27). Over all, the $B: C$ ratio varied in the order of goat dung manure $>$ cow dung manure $>$ RDF $>$ FYM > pig dung manure > vermicompost > control treatment. The highest gross return, lowest net return and $\mathrm{B}$ : $\mathrm{C}$ ratio in $T_{7}$ was due to high cost of vermicompost leading to higher cost of cultivation.

It can be concluded that crop yield and soil health could be driven by the qualitative differences among organic manures. Application of vermicompost in toria crop improved the soil health in terms of carbon and available nutrient status and microbial activities in soil. Vermicompost application increased the yield and yield attributing characteristics of toria crop and was confirmed to be the best over other organic manures. However, feeding the soil with goat dung manure showed the highest available nitrogen besides increasing the net income and benefit: cost ratio compared to other manures under the prevailing climatic condition of Assam of north-eastern region of India.

\section{Acknowledgments}

The first author would like to express his thanks to the Director of Research (Agri.), Assam Agricultural University, Jorhat, Assam for providing financial support for conducting this study.

\section{Add-on Information}

Author's contribution : B. Gogoi: Conducted the study, Planning, Monitoring, and Manuscript writing; B. Kalita: Literature survey; I. Bhupenchandra: Statistical analysis of data; P. Sutradhar: Data acquisition; K.K. Sharma: Helped editing the manuscript.

Research content : The research content of manuscript is original and has not been published elsewhere.

\section{Ethical approval : NotApplicable}

Conflict of interest : The authors declare that there is no conflict of interest.

\section{Data from other sources : NotApplicable}

Consent to publish : All authors agree to publish the paper in Journal of Environmental Biology.

\section{References}

Aher, S.B., B.L. Lakaria, A.B. Singh, S. Kaleshananda, S. Ramana, K. Ramesh, J.K. Thakur, P.S. Rajput and D.S. Yashona: Effect of organic sources of nutrients on performance of soybean (Glycine max). Indian J. Agri. Sci., 89, 1787-1791 (2019).

Atiyeh, R.M., S.S. Lee, C.A. Edwards, N.Q. Arancon and J. Metzger: The influence of humic acid derived from earthworm-processed organic waste on plant growth. Bioresor. Technol., 84, 7-14 (2002).

Avasthe, R.K., S. Babu, R. Singh, G.S. Yadav and A. Kumar: Productivity and profitability assessment of organically grown vegetables embedded in rice based cropping sequences in Sikkim Himalayas, 
North East India. J. Environ. Biol., 41, 111-117 (2020).

Azeez, J.O. and W. Van Averbeke: Dynamics of soil pH and electrical conductivity with the application of three animal manures. Commun. Soil Sci. PlantAnal., 43, 865-874 (2012).

Babu, S., R. Singh, R.K. Avasthe, G.S. Yadav, K.P. Mohapatra, Thiru Selvan, A. Das, V.K. Singh, D. Valente and I. Petrosillo: Soil carbon dynamics in Indian Himalayan intensified organic rice-based cropping sequences. Ecol. Indicators, 114, 106292 (2020).

Baishya, A., J. Hazarika, Gogoi Bhabesh, M. Borah, A.S. Bora, A. Rajbongshi, D. Bordoloi and J.P. Hazarika: Organic nutrient management packages for rice based cropping system under rainfed situation of Assam. In: System Based Organic Nutrient Management. ICAR-Indian Institute of Farming System Research, Modipuram, UP, India (2015b).

Baishya, A., G. Bhabesh, J. Hazarika, M. Borah, J.P. Hazarika, A.S. Bora, A. Rajbongshi, P. Deori and P. Sutradhar: Effect of continuous cropping and integrated nutrient management practices on soil properties and yield of rice-rice cropping system in acid soil. Ind. J. Agron., 60, 493-501 (2015a).

Bujarbaruah, K.M.: Organic farming: opportunities and challenges in North Eastern region of India. In: Souvenir, International Conference on Organic Food 14-17 February, 2004, ICAR Research Complex for NEH Region, Umiam, Meghalaya, pp. 7- 13 (2004).

Choudhary, M., H.S. Jat, A. Datta, A.K. Yadav, T.B. Sapkota, S. Mondal, R.P. Meena, P.C. Sharma and M.L. Jat: Sustainable intensification influences soil quality, biota, and productivity in cereal-based agroecosystems. Appl. Soil Ecol. 126, 189-198 (2018).

Dao, T.H. and M.A. Cavigellib: Mineralizable carbon, nitrogen, and waterextractable phosphorus release from stockpiled and composted manure and manure-amended soils. Agron. J., 95, 405-413 (2003).

Das, A., D.P. Patel, M. Kumar, G.I. Ramkrushna, A. Mukherjee, J. Layek, S.V. Ngachan and J. Buragohain: Impact of seven years of organic farming on soil and produce quality and crop yields in eastern Himalayas, India. Agric. Ecosys. Environ., 236, 142-153 (2017).

Escobar, M.E.O. and N.V. Hue: Temporal changes of selected chemical properties in three manure amended soils of Hawaii. Bioresour. Technol., 99, 8649-8654 (2008).

Fares, A., F. Abbas, A. Ahmad, J.L. Deenik and M. Safeeq: Response of selected soil physical and hydrologic properties to manure amendment rates, levels, and types. Soil Sci., 173, 522-533 (2008).

Gezahegn, A.M. and M.Y. Martini: Effects of residual organic manure and supplemental inorganic fertilizers on performance of subsequent maize crop and soil chemical properties. Int. J. Res. Stud. Agri. Sci., 6, 1-9 (2020).

Ghanshyam, K.R. and R.K. Jat: Productivity and soil fertility as effected by organic manures and inorganic fertilizers in greengram (Vigna radiata)-wheat (Triticum aestivum) system. Ind. J. Agron., 55, 1621 (2010).

Gogoi, Bhabesh, N. G. Barua and T.C. Baruah: Effect of integrated supply of nutrient on soil microbial biomass carbon in an Inceptisol of Assam. J. Ind. Soc. Soil Sci., 58, 241-244 (2010).

Gogoi, B.: Soil properties and nutrients availability as affected by integrated nutrient management after rainfed cropping sequence. Ind. J. Agric. Res., 45, 346-349 (2011).

Gomez, K.A. and A.A. Gomaz: Statistical Procedures for Agricultural Research. John Wiley and Sons, Singapore (1984).
Guzman-Albores, J.M., J.A. Monrtes-Molina, J.H. Castenon-Gonzalez, M. Abud-Archila, F.A. Gulterrez-Miceli and V.M. Ruiz-Valdiviezo: Effect of different vermicompost doses and water stress conditions on plant growth and biochemical profile in medicinal plant, Moringa oleifera. J. Environ. Biol., 41, 240-246 (2020).

Haynes, R.J. and M.S. Mokolobate: Amelioration of Al toxicity and $P$ deficiency in acid soils by additions of organic residues: A critical review of the phenomenon and the mechanisms involved. Nutr. Cycl. Agroecos., 59, 47-63 (2001).

Jackson M.L.: Soil Chemical Analysis. Prentice Hall of India Pvt. Ltd., New Delhi, India (1973).

Jadhao, S.D., D. Arjun, D.V. Mali, M. Singh, V.K. Kharche, R.H. Wanjari, P.R. Kadu, B.A. Sonune and P.N. Magare: Effect of long-term manuring and fertilization on depth wise distribution of potassium fractions under sorghum-wheat cropping sequence in Vertisol. $J$. Ind. Soc. Soil Sci., 66, 172-181 (2018).

Jenkinson, D.S. and D.S. Powlson: The effect of biocidal treatments on metabolism in soil. V. A method for measuring soil biomass. Soil Biol. Biochem., 8, 209-213 (1976).

Kaur, T. and B.S. Brar: Organic matter, microbial biomass and enzyme activity of soil under maize-wheat cropping system. J. Soil Crops, $18,24-30$ (2008).

Lakaria, B.L., M. Singh, K.S. Reddy, A.K. Biswas, P. Jha, R.S. Choudhary, A.B. Singh and A.S. Rao: Carbon addition and storage under integrated nutrient management in soybean-wheat cropping sequence in a Vertisol of central India. Nati. Acad. Sci. Lett., 35, 131-37 (2012).

Lepcha, B., R. Avasthe, R. Singh, N.J. Singh and P. Phukan: Effect of organic nutrient sources on productivity, profitability and quality of ginger (Zingiber officinale) in acid soils of Eastern Himalayas. Indian J. Agric. Sci., 89, 1103-1107 (2019).

Mahapatra, B.S., T. Ramasubramanian and H. Chowdhury: Organic farming for sustainable agriculture: Global and Indian perspective. Indian J. Agron., 54, 178-185 (2009).

Maillard, E. and D.A. Angers: Animal manure application and soil organic carbon stocks: A meta-analysis. Global Chang. Biol., 20, 666-679 (2014).

Manna, M.C., S. Kundu, M. Singh and P.N. Takkar: Influence of FYM on dynamics of microbial biomass and its turonver and activity of enzymes under a soybean-wheat system on a Typic Haplustert. J. Ind. Soc. Soil Sci., 44, 409-412 (1996).

Meelu, O.P., Y. Singh and B. Singh: Green manuring for crop productivity improvement. FAO World Soil Res. Reports, No. 76. FAO, Rome (1994).

Munda, S., B.G. Shivakumar, B. Gangaiah, D.S. Rana, K.M. Manjaiah, K. Lakshman and J. Layek: Response of soybean (Glycine max) to phosphorus with or without biofertilizer. Ind. J. Agron., 58, 86-90 (2013).

Nagar, R.K., V.V. Goud, R. Kumar and R. Kumar: Effect of organic manures and crop residue management on physical, chemical and biological properties of soil under pigeonpea based intercropping system. Int. J. Farm Sci., 6, 101-113 (2016).

Nardi, S., F. Morari, A. Berti, M. Tosoni and L. Giardini: Soil organic matter properties after 40 years of different use of organic and mineral fertilizers. European J. Agron., 21, 357-367 (2004).

Nayak, A.K., B. Gangwar, A.K. Shukla, S.P. Majumdar, A. Kumar, V. Kumar and U. Mohan: Long-term effect of different integrated nutrient management on soil organic carbon and its fractions and sustainability of rice-wheat system in Indo-Gangetic plains of India. Field Crop Res., 127, 129-139 (2012). 
Ould Ahmed, B.A., M. Inoue and S. Moritani: Effect of saline water irrigation and manure application on the available water content, soil salinity, and growth of wheat. Agric. Water Manag., 97, 165170 (2010).

Patel, G., B.S. Dwivedi, A.K. Dwivedi, R. Thakur and M. Singh: Long-term effect of nutrient management on soil biochemical properties in a Vertisol under soybean-wheat cropping sequence. J. Ind. Soc. Soil Sci., 66, 215-221 (2018).

Patra, P.S., A.C. Sinha and S.S. Mahesh: Yield, nutrient uptake and quality of groundnut (Arachis hypogaea) kernels as affected by organic sources of nutrient. Ind. J. Argon., 56, 237-241 (2011).

Rahman, M.H., M.R. Islam, M. Jahiruddin, A.B. Puteh and M.M.A. Mondal: Influence of organic matter on nitrogen mineralization pattern in soils under different moisture regimes. Int. J. Agri. Biol., 15, 55-61 (2013).

Ram, R.A., A. Singha and V.K. Singh: Improvement in yield and fruit quality of mango (Mangifera indica) with organic amendments. Ind. J. Agric. Sci., 89, 1429-1433, (2019).

Ramesh, P., M. Singh and A. Subba Rao: Organic farming: Its relevance to the Indian context. Curr. Sci., 88, 561-568 (2005).

Rana, K.S., A.K. Choudhary, S. Sepat, R.S. Bana and A. Das: Methodological and Analytical Agronomy. IARI, New Delhi (2014).

Roy, S. and Md.A. Kashem: Effects of organic manures in changes of some soil properties at different incubation periods. Open J. Soil Sci. 4, 81-86 (2014).

Sanker, V., Veragagavathatham and M. Kanna: Organic farming practices in white onion (Allium cepa L.). J. Eco-friendly Agric., 4, 17-21 (2009).

Subbiah B.V. and G.L. Asija: A rapid procedure for the determination of available nitrogen in soils. Cur. Sci., 25, 259-260 (1956).

Swarup, A. and R.H. Wanjari: Three decades of All India Coordinated Research Long Term Fertilizer Experiments for studying changes in fertility crop productivity and sustainability. ICAR-Indian Institute of Soil Science, Bhopal, India (2000).

Timsina, J. and D.J. Connor: Productivity and management of rice-wheat systems: Issues and challenges. Field Crops Res., 69, 93-132 (2001).

Vance, E.D., P.C. Brookes and D.S. Jenkinson: An extraction method for measuring soil microbial biomass C. Soil Bio. Biochem., 19, 703707 (1987a).

Vance, E.D., P.C. Brookes and D.S. Jenkinson: Microbial biomass measurements in forest soils: the use of chloroform fumigationincubation methods for strongly acidic soil. Soil Bio. Biochem., 19, 697-702 (1987b).

Vel Murugan, A. and T.P. Swarnam: Nitrogen release pattern from organic manures applied to an acid soil. J. Agric. Sci., 5, 74-184 (2013).

Vipitha, V.P. and V.L. Geethakumari: Bio-organic composite manures for sustainable yield and quality of amaranth (Amaranthus tricolor). Indian J. Agron., 60, 471-475 (2015).

Walkley A. and I.A. Black: An examination of the Degtjareff method for determining soil organic matter and a proposed modification of the chromic acid titration method. Soil Sci., 37, 29-38 (1934).

Watson, C.A., D. Atkinson, P. Gosling, L.R. Jackson and F.W. Rayns: Managing soil fertility in organic farming systems. Soil Use Manag., 18, 239-247 (2002).

Wong, M.T.F. and R.S. Swift: Role of organic matter in alleviating soil acidity. In: Handbook of Soil Acidity (Ed.: Z. Rengel), Marcel Dekker, Inc., New York, pp. 337-358, (2003).

Yadav, S.K., B. Subhash, M.K. Yadav, K. Singh, G.S. Yadav and P. Suresh: A review of organic farming for sustainable agriculture in northern india. Int. J. Agron., 15, 56-62 (2013).

Zhang, J.B., J. Yang, R. Yao, S. Yu, F. Li and X. Hou: The effects of farmyard manure and mulch on soil physical properties in a reclaimed coastal tidal flat salt-affected soil. J. Integrat. Agric., 13, $1782-1790$ (2014).

Zhao, Y., Y. Zhang, X. Liu, X. He and X. Shi: Carbon sequestration dynamic, trend and efficiency as affected by 22-year fertilization under a rice-wheat cropping system. J. Plant Nut. Soil Sci., 179, 652-660 (2016). 